Tropical Journal of Pharmaceutical Research June 2015; 14 (6): 1111-1117

ISSN: $1596-5996$ (print); 1596-9827 (electronic)

(C) Pharmacotherapy Group, Faculty of Pharmacy, University of Benin, Benin City, 300001 Nigeria.

All rights reserved.

Available online at http://www.tjpr.org

Review Article

http://dx.doi.org/10.4314/tjpr.v14i6.25

\title{
Potential Beneficial Effects of Tulbaghia violacea William Henry Harvey (Alliaceae) on Cardiovascular System - A Review
}

\author{
Ismaila Raji ${ }^{1}$, Kenechukwu Obikeze ${ }^{2}$ and Pierre Mugabo ${ }^{2}$ \\ ${ }^{1}$ Faculty of Medicine, National University of Science and Technology, Zimbabwe, ${ }^{2}$ School of Pharmacy, University of the \\ Western Cape, South Africa
}

*For correspondence: Email: ismailaraji@gmail.com

Received: 9 May 2014

Revised accepted: 19 April 2015

\begin{abstract}
Tulbaghia violacea William Henry Harvey (Harv. Alliaceae) is a small bulbous herb belonging to the family Alliaceae. It is used in South Africa to treat fever, colds, asthma, paralysis, and hypertension. Meanwhile, cardiovascular disease accounts for about $30 \%$ of total global death, with most of these deaths occurring in low and middle-income countries. Furthermore, people in low-income countries are still largely dependent on plants in their surroundings for both prophylaxis and treatment of diseases, partly due to limited access to and cost of pharmaceuticals, and folkloric evidence of the potency of medicinal plants and/or local belief systems. Therefore, the present review aims to proffer possible ways by which T. violacea may improve cardiovascular outcomes. An extensive and systematic review of the literature was carried out, and relevant findings presented in this review. There is evidence that $T$. violacea may modulate the renin-angiotensin system, the autonomic nervous system, oxidative stress and haemostasis, with resultant protection of the cardiovascular system in both health and disease.
\end{abstract}

Keywords: Tulbaghia violacea, Spontaneously hypertensive rats, Hypertension, Blood pressure, Heart rate, Renin-angiotensin aldosterone system

Tropical Journal of Pharmaceutical Research is indexed by Science Citation Index (SciSearch), Scopus, International Pharmaceutical Abstract, Chemical Abstracts, Embase, Index Copernicus, EBSCO, African Index Medicus, JournalSeek, Journal Citation Reports/Science Edition, Directory of Open Access Journals (DOAJ), African Journal Online, Bioline International, Open-J-Gate and Pharmacy Abstracts

\section{INTRODUCTION}

Cardiovascular disease (CVD) is a complex multi-factorial disease [1]. It accounts for $29.2 \%$ of total global deaths, with approximately $80 \%$ of these deaths occurring in low and middle-income countries [2]. Epidemiologic studies indicate that hypertension (HTN), elevated serum lipids, increased plasma fibrinogen and coagulation factors, increased platelet activation, alterations in glucose metabolism (diabetes mellitus, DM), and smoking are factors positively associated with CVD [3]. Sixty per cent of the burden of CVD and about $50 \%$ of that of coronary heart disease (CHD) globally is caused by HTN [3]. Age [4], gender [5], urbanization [6], obesity [7] and certain dietary factors [8] strongly influence the occurrence of essential HTN. Although, some of the present chemical drugs have shown a lot of promise in the treatment of HTN, many patients usually need to use a combination of agents from the different classes of antihypertensive agents presently in the market to achieve the desired therapeutic goals, leading to problems with adherence to therapeutic regimes [9]. Furthermore, uncontrolled blood pressure (BP) has also been reported in a high number of hypertensive patients who adhere to the available antihypertensive drugs and/or therapy [10], given impetus to intensive research towards 
discovering better, cheaper and equally effective medicines, including herbs [11].

\section{PLANTS IN CARDIOVASCULAR DISEASE}

Plants have formed the basis of sophisticated traditional medicine systems that have been in existence for thousands of years and continue to provide mankind with new remedies, and about $80 \%$ of the population of the world may still rely on plant-derived medicines for their healthcare needs [12]. In recent times, there has been a rekindling of interest in 'rediscovering natural products' [13]. Previous works on medicinal plants led to the isolation of early drugs such as cocaine, codeine, digitoxin, quinine, diosgenin, reserpine, pilocarpine and morphine [12]. Some plants which have been previously reported to have potential beneficial effects against CVD include Allium sativum (garlic) [14], Rauwolfia serpentina (Apocynaceae) Radix rauwolfiae (snake-root) [15], Curcuma longa (turmeric) [16], Crataegus monogyna (Hawthorn) and Crataegus laevigata (Hawthorn thorny) leaves, flowers and berries [17], Salvia miltiorrhiza (red sage, Danshen) [18], Ocimum gratissimum L. (Labiatae) [19], Andrographis paniculata [20], and Tulbaghia violacea [21-23]. The list is endless, however this review will be geared towards one of such plant: T. violacea.

\section{Tulbaghia violacea}

Tulbaghia violacea Harv. (Alliaceae) is a small bulbous herb, with attractive purple flowers, arising from a white fleshy stalk (figure 1 below).
It belongs to the same family as onions and garlic, Alliaceae. The plant is widespread throughout Africa, with the greatest concentration in Southern Africa, where it is known locally as wilde knoffel (Afrikaans), isihaqa (Zulu) or itswele lomlambo (Xhosa) [24]. It is widely used as herbal remedy for various ailments such as fever, colds, asthma, tuberculosis, rheumatism, paralysis, HTN, stomach problems and oesophageal cancer; with its leaves and bulbs being the parts most commonly used. However, adverse effects such as gastroenteritis, abdominal pain, acute inflammation, sloughing of the intestinal mucosa, contraction of the pupils, as well as fatalities has also been reported with treatment with extracts of the plant [23,24].

T. violacea has been postulated to have similar secondary metabolites and hence biological activities as garlic since they belong to the same family; and both have the characteristic sulphur smell associated with garlic [23,24]. Sulphur compounds have been isolated from both garlic and $T$. violacea, and are credited with the medicinal properties of garlic [25,26]. These sulphur-containing compounds are produced when alliinase, an enzyme present in all plants belonging to the Allium species, reacts with alliin when the plant is bruised/ crushed [25]. Numerous odour forming compounds $[25,26]$ and bioflavonoids such as quercetin [27] have also been isolated from extracts of $T$. violacea. The optimum $\mathrm{pH}$ for activity of alliinase from both garlic and $T$. violacea is 6.5 , and that for onion 8 [28].

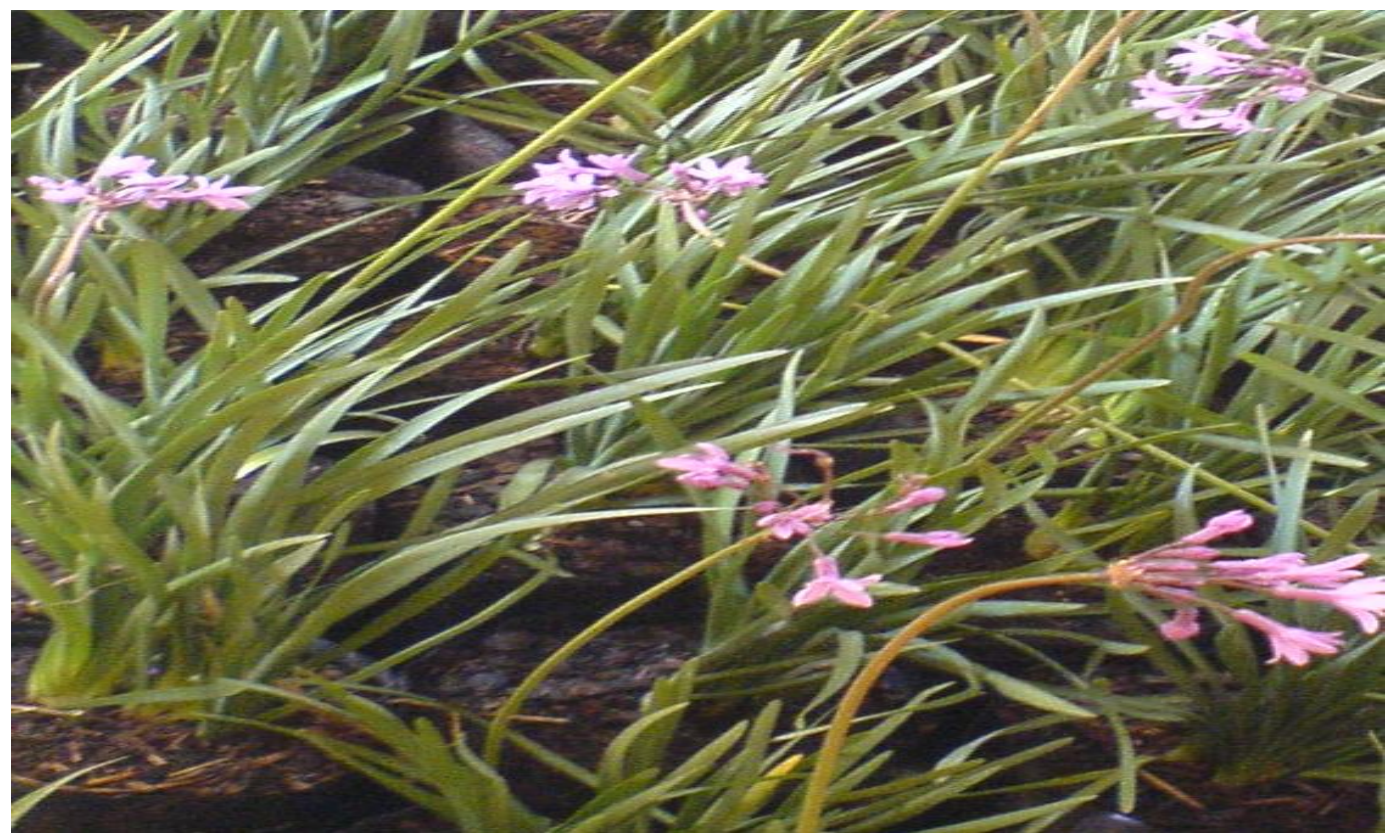

Figure 1: Tulbaghia violacea (with green leaves and purple flowers) 
There is extensive clinical, epidemiological, invivo and in-vitro research on the beneficial effects of garlic on the cardiovascular system (CVS) [14]. However, there are only a few in-vivo and in-vitro reports in literature for $T$. violacea and these are due to a recent burst of research into it $[11,21,22,29-33]$. The present review will discuss the possible modulatory action of $T$. violacea on the renin-angiotensin aldosterone system, the autonomic nervous system, oxidative stress and haemostasis and the beneficial effects for cardiovascular diseases.

\section{Effects of TV on the renin angiotensin aldosterone system}

The renin angiotensin aldosterone system (RAAS) is a key physiologic regulator of vascular tone, salt and water balance, blood pressure $(\mathrm{BP})$, bradykinin system and pituitary gland hormones [34]. Chronic activation of the RAAS results in HTN, vascular and myocardial hypertrophy, left ventricular remodelling, atherosclerosis, and glomerulosclerosis [34]. $T$. violacea has been reported to display angiotensin converting enzyme (ACE) inhibitory activity in vitro [31] and in vivo [11,22,32,33]. Extracts of $T$. violacea have been reported to reduce systolic blood pressure (SBP) in response to infusion of ang $I$ in anaesthetized male spontaneously hypertensive Wistar rats (SHR) [11,21] and in normotensive male Wistar rats [33] when compared to the corresponding values in the control rat groups in acute experiments. A similar finding was replicated in chronic experiments involving Dahl salt sensitive rats (DSS) [22,32], but not in SHR [21] (Table 1, Figure 2).

Angiotensin II (ang II) is the most powerful biologically active product of the RAAS. It directly constricts vascular smooth muscle (VSM) and the cells (VSMCs), enhances myocardial contractility, stimulates aldosterone production, blunts the baroreflex, stimulates the release of catecholamines from the adrenal medulla and sympathetic nerve endings, increases sympathetic nervous system activity, stimulates thirst and salt appetite, and increases sodium and water reabsorption. It also induces inflammation, cell growth, mitogenesis, apoptosis, migration, and differentiation, regulates the gene expression of bioactive substances, reactive oxygen species, and activates multiple intracellular signalling pathways $[38,39]$. Consequently, ang II plays an important role in atherosclerosis, with most of its hypertensinogenic actions mediated through the angiotensin II type $1\left(\mathrm{AT}_{1}\right)$ receptor; although an angiotensin II type $2\left(\mathrm{AT}_{2}\right)$ receptor exists [34]. The lack of a significant change in final BP values obtained with co-infusion of $T$. violacea and ang II, when compared to the infusion of ang II alone in the SHR in the study conducted by Raji et al [11] may suggest that $T$. violacea

Table 1: Cardiovascular effects of Tulbaghia violacea extracts

\begin{tabular}{|c|c|c|c|c|c|}
\hline $\begin{array}{l}\text { Reference } \\
\text { number }\end{array}$ & $\begin{array}{l}\text { Animal } \\
\text { used }\end{array}$ & $\begin{array}{l}\text { Type of } \\
\text { study }\end{array}$ & $\begin{array}{l}\text { Plant } \\
\text { part }\end{array}$ & $\begin{array}{c}\text { Plant } \\
\text { preparation }\end{array}$ & Results \\
\hline [35] & N/A & in-vitro & $\begin{array}{l}\text { Leaf, } \\
\text { Roots }\end{array}$ & $\begin{array}{l}\text { Aqueous \& } \\
\text { Methanol }\end{array}$ & ACE inhibition \\
\hline [24] & N/A & in-vitro & $\begin{array}{l}\text { Leaf, } \\
\text { Bulb }\end{array}$ & $\begin{array}{l}\text { Aqueous \& } \\
\text { methanol }\end{array}$ & Anticoagulant \& antithrombotic activities \\
\hline [36] & N/A & in-vivo & $\begin{array}{l}\text { Whole } \\
\text { plant }\end{array}$ & Aqueous & Antioxidant activity \\
\hline [33] & NWR & $\begin{array}{l}\text { in-vitro } \\
\text { in-vivo }\end{array}$ & Leaf & $\begin{array}{l}\text { Aqueous \& } \\
\text { methanol }\end{array}$ & ACE inhibition; reduction in MAP \\
\hline [29] & $\mathrm{N} / \mathrm{A}$ & in-vitro & Bulb & Methanol & Anticoagulant \& antithrombotic activities \\
\hline [32] & DSS & in-vivo & Leaf & Aqueous & $\begin{array}{l}\text { Reduction in } \mathrm{AT}_{1} \text { a mRNA expression \& } \\
\text { SBP; increased diuresis \& natriuresis }\end{array}$ \\
\hline [37] & NWR & in-vivo & Root & Methanol & Antioxidant activity \\
\hline [30] & DIATR & in-vivo & Root & Methanol & Improved lipid profile \& antioxidant activity \\
\hline [11] & SHR & in-vivo & Leaf & Methanol & $\begin{array}{l}\text { Reduced SBP, MAP, DBP \& HR; ACE } \\
\text { inhibition \& } \beta 1 \text { adrenoceptor blockade }\end{array}$ \\
\hline [22] & DSS & in-vivo & Root & Methanol & $\begin{array}{c}\text { Decrease SBP; increased diuresis \& } \\
\text { natriuresis }\end{array}$ \\
\hline [21] & SHR & in-vivo & Leaf & Methanol & $\begin{array}{c}\text { Reduced plasma aldosterone levels, SBP, } \\
\text { MAP, DBP \& HR; stimulated muscarinic } \\
\text { receptors }\end{array}$ \\
\hline
\end{tabular}




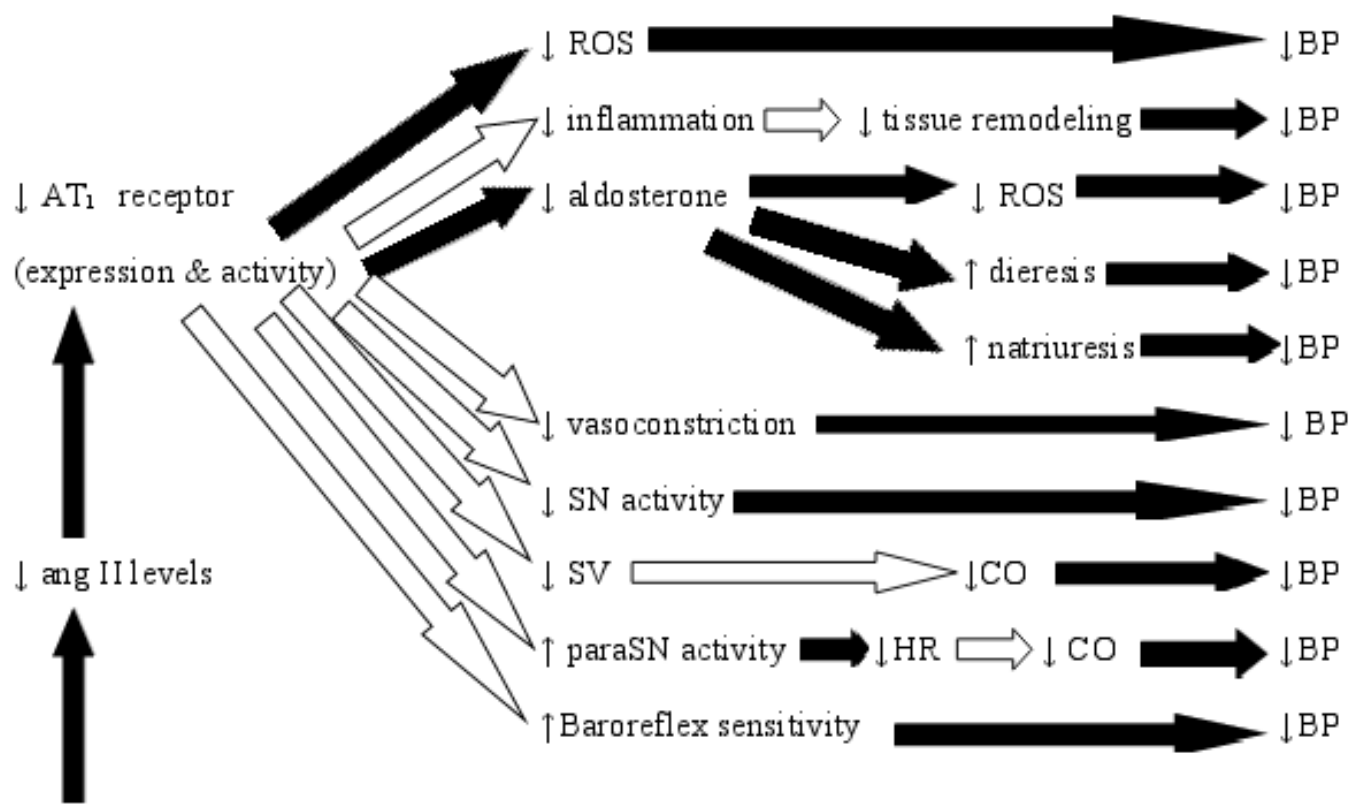

$\uparrow$ Tulbaghia violacea

Figure 2: Possible mechanism of action of Tulbaghia violacea. The dark arrows indicate mechanisms already reported in literature, while the light arrows indicate proposed mechanisms. Increased $(\uparrow)$, decreased $(\downarrow)$, blood pressure (BP), angiotensin II (ang II), angiotensin II type 1 (AT 1 ) receptor, reactive oxygen species (ROS), sympathetic nerve $(\mathrm{SN})$, parasympathetic nerve (paraSN), stroke volume $(\mathrm{SV})$, cardiac output $(\mathrm{CO})$, heart rate $(\mathrm{HR})$

may not directly inhibit the $A T_{1}$ receptor. However, enhanced natriuresis has been reported with chronic treatment of DSS with $T$. violacea [22,32]. This was associated with downregulation of the $A T_{1}$ a mRNA in one study [32], but was not associated with down-regulation of the $\mathrm{AT}_{1}$ a mRNA in another [22] (Table 1, Figure 2 ), which may suggest that the plant may produce its natriuretic action via other mechanisms or receptors, aside the $\mathrm{AT}_{1} \mathrm{a}$.

Aldosterone is a mineralocorticoid synthesized in the zona glomerulosa of the adrenal gland in response to ang II, adrenocorticotropin and potassium. It regulates electrolyte, fluid balance and BP homeostasis [40]. It also mediates maladaptive tissue remodelling throughout the cardiovascular and central nervous system. Primary hyperaldosteronism leads to a greater frequency of resistant HTN, as well as CVD and chronic kidney disease (CKD) morbidity and mortality, compared with essential HTN [41]. Reducing plasma aldosterone levels may be a third point of intervention of $T$. violacea in the RAAS, with inhibition of ACE and AT1a mRNA expression being the first and second respectively. Interestingly, chronic infusion of $T$. violacea resulted in significant reduction $(p<$ 0.05 ) in plasma aldosterone levels in two studies in SHR [21] and DSS [32] (Table 1, Figure 2), but this reduction was not observed in a third study [22].

\section{Effects of TV on the autonomic nervous system}

The VSMCs are the major cellular component of the vascular media and mediate vasodilatation and vasoconstriction; and are innervated by both sympathetic and parasympathetic fibres [42]. The autonomic nervous system (ANS) consists of both the sympathetic and parasympathetic nervous systems, the activities of both systems are normally in dynamic balance, and plays a vital role in the control of cardiovascular activity [43]. Interestingly, a large proportion of patients with HTN have increased sympathetic activity, associated with decreased parasympathetic activity [44]. Adrenoceptors mediate the actions of the sympathetic nervous system [45]. Stimulation of the beta $1(\beta 1)$ adrenoceptors in the heart produces increases in heart rate $(H R)$, cardiac output, and ultimately BP [46]. Inhibition of the $\beta 1$ adreonoceptors by $T$. violacea may have contributed to the bradycardia, associated with reduction in BP observed in the SHR [11] (Table 1, Figure 2). Resting $H R$ is an independent predictor of both cardiovascular and "all-cause" mortality in men and women with or without a diagnosed CVD [45], therefore agents that can reduce $H R$ are beneficial to the CVS. The neurotransmitter of the parasympathetic nervous system is acetylcholine, and it acts via nicotinic and muscarinic receptors. Activation of 
the muscarinic receptors in the heart leads to bradycardia [47]. T. violacea may have an effect on the muscarinic receptors, since pre-treatment of SHR with atropine, blocked the bradycardia of its methanolic extract [21] (Table 1, Figure 2).

\section{Effects of TV on oxidative stress and haemostasis}

Oxidative stress, characterized by an imbalance between the generation of reactive oxygen species (ROS) and the capacity of the intrinsic antioxidant defense system, has been implicated in the pathogenesis of CVD, including HTN [39]. ROS are important as signaling molecules and are produced continuously from oxygen in cells to support normal cellular functions such as proliferation and migration [48,49], but may result in cell injury when excessively produced, and have been implicated in a host of pathological processes, including vascular hypertrophy and remodelling, HTN, inflammation and atherosclerosis $[38,49]$. The established therapeutics against atherosclerosis are largely focused on alleviating hypertension and hyperlipidaemia or controlling haemostasis to prevent thrombotic complications [50]. To this end, $T$. violacea has been reported to improve lipid profile [30]; and have both anti-oxidant $[30,37]$, and anti-thrombotic [24,29] properties (Table 1, Figure 2).

\section{RECOMMENDATIONS}

The traditional use of $T$. violacea in the treatment of HTN may be encouraged, although further studies are required, to not only ascertain its safety and optimal dose, but to also isolate and remove constituents that may negate the potency of the anti-hypertensive constituent(s). It will also be crucial to investigate the effect of temperature on the active constituent(s), as well as the first pass metabolism, the bioavailability when taken orally, the rate of metabolism in the body, the distribution, the half life, toxicity and also the route(s) of elimination of its constituents. Finally, an assessment into its interaction with other herbs, drugs or food in both experimental animals and in clinical trials would be required.

\section{CONCLUSION}

Various studies have shown that $T$. violacea has a wide-ranging effect on the cardiovascular system by modulating the renin-angiotensin aldosterone system, the autonomic nervous system, oxidative stress and haemostasis.

\section{REFERENCES}

1. Rahman K, Lowe GM. Garlic and cardiovascular disease: a critical review. J Nutr 2006; 136(3 Suppl): 736S740 S.

2. World Health Organization. Prevention of cardiovascular disease: guidelines for assessment and management of total cardiovascular risk. World Health Organization. 9789241547178. 2007.

3. Seedat YK. Impact of poverty on hypertension and cardiovascular disease in sub-Saharan Africa. Cardiovascular journal of Africa 2007; 18(5): 316-320.

4. Chalmers J. World Health Organization International Society of Hypertension guidelines for the management of hypertension. J. Hypertens. 1999; 17: 151-83.

5. Kelly DM, Jones TH. Testosterone: a vascular hormone in health and disease. Journal of Endocrinology 2013; 217(3): R47-R71.

6. van Rooyen JM, Kruger HS, Huisman HW, Wissing MP, Margetts BM, Venter CS, Vorster $\mathrm{HH}$. An epidemiological study of hypertension and its determinants in a population in transition: the THUSA study. J Hum Hypertens 2000; 14(12): 779-787.

7. Stampfer MJ, Sacks FM, Salvini S, Willett WC, Hennekens $\mathrm{CH}$. A prospective study of cholesterol, apolipoproteins, and the risk of myocardial infarction. N Engl J Med 1991; 325(6): 373-381.

8. Appel LJ, Moore TJ, Obarzanek E, Vollmer WM, Svetkey LP, Sacks FM, Bray GA, Vogt TM, Cutler JA, Windhauser MM, et al. A clinical trial of the effects of dietary patterns on blood pressure. DASH Collaborative Research Group. N Engl J Med 1997; 336(16): 1117-1124.

9. De Sevo G, Klootwyk J. Pharmacologic issues in management of chronic disease. Prim Care 2012; 39(2): 345-362.

10. Volpe $M$, Tocci $G$. Rationale for triple fixed-dose combination therapy with an angiotensin II receptor blocker, a calcium channel blocker, and a thiazide diuretic. Vasc Health Risk Manag 2012; 8: 371-380.

11. Raji IA, Mugabo P, Obikeze K. Effect of Tulbaghia violacea on the blood pressure and heart rate in male spontaneously hypertensive Wistar rats. J Ethnopharmacol 2012; 140(1): 98-106.

12. Gurib-Fakim A. Medicinal plants: Traditions of yesterday and drugs of tomorrow. Mol Aspects Med 2006; 27(1): 1-93.

13. Cragg GM, Newman DJ. Biodiversity: A continuing source of novel drug leads. Pure Appl.Chem 2005; 77(1): 7-24.

14. Qidwai W, Ashfaq T. Role of Garlic Usage in Cardiovascular Disease Prevention: An EvidenceBased Approach. Evid Based Complement Alternat Med 2013; 2013: 9.

15. Slim HB, Black HR, Thompson PD. Older blood pressure medications-do they still have a place? Am J Cardiol 2011; 108(2): 308-16.

Trop J Pharm Res, June 2015; 14(6): 1115 
16. Correa F, Buelna-Chontal M, Hernandez-Resendiz S, W RG-N, F JR, Soto V, Silva-Palacios A, Amador A, Pedraza-Chaverri J, Tapia E, et al. Curcumin maintains cardiac and mitochondrial function in chronic kidney disease. Free Radic Biol Med 2013; 61C: 119-129.

17. Zhang J, Liang R, Wang L, Yan R, Hou R, Gao S, Yang $B$. Effects of an aqueous extract of Crataegus pinnatifida Bge. var. major N.E.Br. fruit on experimental atherosclerosis in rats. $J$ Ethnopharmacol 2013; 148(2): 563-569.

18. Li CM, Dong $X L$, Fan $X D, W u J H$, Wang $Q H$, Tian $X L$, Guo DJ, Wong MS, Qiu TQ, Chan SW. Aqueous extract of danshen (Salvia miltiorrhiza Bunge) protects ovariectomized rats fed with high-fat diet from endothelial dysfunction. Menopause 2013; 20(1): 100-9.

19. Pires AF, Madeira SV, Soares PM, Montenegro CM, Souza EP, Resende AC, Soares de Moura R, Assreuy AM, Criddle DN. The role of endothelium in the vasorelaxant effects of the essential oil of Ocimum gratissimum in aorta and mesenteric vascular bed of rats. Can J Physiol Pharmacol 2012; 90(10): 1380-5.

20. Jayakumar T, Hsieh CY, Lee JJ, Sheu JR. Experimental and Clinical Pharmacology of Andrographis paniculata and Its Major Bioactive Phytoconstituent Andrographolide. Evid Based Complement Alternat Med 2013; 2013: 846740.

21. Raji I, Mugabo P, Obikeze K. The contributions of muscarinic receptors and changes in plasma aldosterone levels to the anti-hypertensive effect of Tulbaghia violacea. BMC Complement Altern Med 2013; 13(1): 13.

22. Moodley K, Mackraj I, Naidoo Y. Cardiovascular effects of Tulbaghia violacea Harv. (Alliaceae) root methanolic extract in Dahl salt-sensitive (DSS) rats. J Ethnopharmacol 2013; 146(1): 225-31.

23. Aremu AO, van Staden J. The genus Tulbaghia (Alliaceae)-A review of its ethnobotany, pharmacology, phytochemistry and conservation needs. J Ethnopharmacol 2013; 149(2): 387-400.

24. Bungu L, van de Venter M, Frost $C$. Evidence for an in vitro anticoagulant and antithrombotic activity in Tulbaghia violacea. African Journal of Biotechnology 2008; 7(6): 681-688.

25. Kubec $R$, Velä-sek J, Musah RA. The amino acid precursors and odor formation in society garlic (Tulbaghia violacea Harv.). Phytochemistry 2002; 60(1): 21-25.

26. Kubec $R$, Krejčová $P$, Mansur L, Garcia N. Flavor Precursors and Sensory-Active Sulfur Compounds in Alliaceae Species Native to South Africa and South America. J Agric Food Chem 2013; 61(6): 1335-1342.

27. Hutchings Anne, Scott Alan Haxton, Lewis Gillian, Cunningham Anthony B. Zulu Medicinal Plants: An Inventory. Pietermaritzburg, South Africa: University of Natal Press; 1996. 464 p.
28. Nock LP, Mazelis M. The C-S Lyases of Higher Plants: Direct Comparison of the Physical Properties of Homogeneous Alliin Lyase of Garlic (Allium sativum) and Onion (Allium cepa). Plant Physiol 1987; 85(4): 1079-1083.

29. Davison C, Levendal R, Frost C. Cardiovascular benefits of an organic extract of Tulbaghia violacea: Its anticoagulant and anti-platelet properties. Journal of Medicinal Plants Research 2012; 6(33): 4815-4824.

30. Olorunnisola OS, Bradley G, Afolayan AJ. Protective Effect of Tulbaghia violacea Harv. on Aortic Pathology, Tissue Antioxidant Enzymes and Liver Damage in Diet-Induced Atherosclerotic Rats. International journal of molecular sciences 2012; 13(10): 12747-12760.

31. Mackraj I, Ramesar S. ACE inhibitor activity of nutritive plants in Kwa-Zulu Natal. The FASEB Journal 2007; 21(906): 13.

32. Mackraj I, Ramesar S, Singh M, Govender T, Baijnath H, Singh $R$, Gathiram $P$. The in vivo effects of Tulbhagia violacea on blood pressure in a salt-sensitive rat model. J Ethnopharmacol 2008; 117(2): 263 -269.

33. Ramesar S, Baijnath $H$, Govender T, Mackraj $I$. Angiotensin l-converting enzyme inhibitor activity of nutritive plants in KwaZulu-Natal. J Med Food 2008; 11(2): 331-336.

34. Gradman AH. Evolving understanding of the reninangiotensin-aldosterone system: Pathophysiology and targets for therapeutic intervention. Am Heart $J$ 2009; 157(6, Supplement 1): S1-S6.

35. Duncan AC, Jager AK, van Staden J. Screening of Zulu medicinal plants for angiotensin converting enzyme (ACE) inhibitors. J Ethnopharmacol 1999; 68(1-3): 63-70.

36. Naidoo V, McGaw LJ, Bisschop SPR, Duncan N, Eloff $J N$. The value of plant extracts with antioxidant activity in attenuating coccidiosis in broiler chickens. Vet Parasitol 2008; 153(3-4): 214-219.

37. Olorunnisola OS, Bradley G, Afolayan AJ. Protective Effect of $T$. violacea Rhizome Extract Against Hypercholesterolemia-Induced Oxidative Stress in Wistar Rats. Molecules 2012; 17(5): 6033-6045.

38. Rodriguez-Iturbe $B$, Franco $M$, Johnson RJ. Impaired pressure natriuresis is associated with interstitial inflammation in salt-sensitive hypertension. Curr Opin Nephrol Hypertens 2013; 22(1): 37-44.

39. Montezano AC, Touyz RM. Reactive Oxygen Species, Vascular Noxs, and Hypertension: Focus on Translational and Clinical Research. Antioxid Redox Signal 2013.

40. Connell JM, Davies E. The new biology of aldosterone. J Endocrinol 2005; 186(1): 1-20.

41. Tomaschitz A, Ritz E, Pieske B, Rus-Machan J, Kienreich $K$, Verheyen N, Gaksch M, Grubler M, FahrleitnerPammer A, Mrak $P$, et al. Aldosterone and parathyroid hormone interactions as mediators of metabolic and cardiovascular disease. Metabolism 2014; 63(1): 20-31.

Trop J Pharm Res, June 2015; 14(6): 1116 
42. Günthner T, Jankowski V, Kretschmer A, Nierhaus $M$, van der Giet M, Zidek W, Jankowski J. Endothelium and Vascular Smooth Muscle Cells in the Context of Uremia. Semin Dial 2009; 22(4): 428-432.

43. Thayer JF, Yamamoto SS, Brosschot JF. The relationship of autonomic imbalance, heart rate variability and cardiovascular disease risk factors. Int J Cardiol 2010; 141(2): 122-131.

44. Joyner MJ, Charkoudian N, Wallin BG. Sympathetic Nervous System and Blood Pressure in Humans. Individualized Patterns of Regulation and Their Implications. Hypertension 2010; 56(1): 10-16.

45. Poirier L, Lacourciere Y. The evolving role of betaadrenergic receptor blockers in managing hypertension. Can J Cardiol 2012; 28(3): 334-340.
46. Weir MR. Beta-blockers in the treatment of hypertension: are there clinically relevant differences? Postgrad Med 2009; 121(3): 90-98.

47. Pleuvry BJ. Drugs affecting the autonomic nervous system. Pain 2008; 9(2): 84-87.

48. Schippers JH, Nguyen HM, Lu D, Schmidt R, MuellerRoeber B. ROS homeostasis during development: an evolutionary conserved strategy. Cell Mol Life Sci 2012; 69(19): 3245-3257.

49. De Marchi E, Baldassari F, Bononi A, Wieckowski MR, Pinton $P$. Oxidative stress in cardiovascular diseases and obesity: role of p66Shc and protein kinase C. Oxid Med Cell Longev 2013; 2013: 564961.

50. Frohlich J, Al-Sarraf A. Cardiovascular risk and atherosclerosis prevention. Cardiovasc Pathol 2013; 22(1): 16-18. 